\title{
The APOB gene polymorphism in the pathogenesis of gallstone disease in pre- and postmenopausal women
}

\author{
Karolina Rudzińska ${ }^{1}$, Anna Bogacz ${ }^{2,3}$, Daniel Kotrych4 ${ }^{4}$, Hubert Wolski ${ }^{5,6}$, Marian Majchrzycki \\ Agnieszka Seremak-Mrozikiewicz ${ }^{3,5,8}$, Bogusław Kosiński ${ }^{9}$, Bogusław Czerny ${ }^{10,11}$
}

\author{
${ }^{1}$ Department of Internal Medicine, $109^{\text {th }}$ Military Hospital, Szczecin, Poland \\ ${ }^{2}$ Laboratory of Experimental Pharmacogenetics, Department of Clinical Pharmacy and Biopharmacy, University of Medical Sciences, \\ Poznan, Poland \\ ${ }^{3}$ Department of Pharmacology and Phytochemistry, Institute of Natural Fibres and Medicinal Plants, Poznan, Poland \\ ${ }^{4}$ Department of Orthopedics and Traumatology, Pomeranian Medical University, Szczecin, Poland \\ ${ }^{5}$ Division of Perinatology and Women's Diseases, Poznan University of Medical Sciences, Poznan, Poland \\ ${ }^{6}$ Division of Gynecology and Obstetrics, Podhale Multidisciplinary Hospital, Nowy Targ, Poland \\ 'Department of Rheumatology and Rehabilitation, Poznan University of Medical Sciences, Poznan, Poland \\ ${ }^{8}$ Laboratory of Molecular Biology in Division of Perinatology and Women's Diseases, Poznan University of Medical Sciences, Poznan, \\ Poland \\ ${ }^{9}$ West Pomeranian Center of Oncology, Division of Surgical Oncology, Szczecin, Poland \\ ${ }^{10}$ Department of General Pharmacology and Pharmacoeconomics, Pomeranian Medical University, Szczecin, Poland \\ ${ }^{11}$ Department of Stem Cells and Regenerative Medicine, Institute of Natural Fibres and Medicinal Plants, Poznan, Poland
}

\begin{abstract}
Aim of the study: The decrease in estrogen levels in the postmenopausal period changes the lipid profile by the expression of hepatic genes related to metabolism of cholesterol and bile acid synthesis that could be important in the pathogenesis of cholelithiasis. The aim of the study was to determine the APOB gene $7673 C>T$ and $12669 \mathrm{G}>\mathrm{A}$ polymorphisms in the pathogenesis of gallstones and analysis of the composition of gallstones in pre- and postmenopausal women.

Material and methods: The study group consisted of 94 women qualified to the laparoscopic cholecystectomy while the control group consisted of 81 women in whom gallstones and other changes in the bile ducts were excluded. Gallstones composition analysis was performed using commercially available assays. The prevalence of the $A P O B$ gene polymorphisms was determined using the polymerase chain reaction and restriction fragment length polymorphism (PCR-RFLP).

Results: When assessing the composition of gallstones in pre- and postmenopausal women, we observed differences in the studied parameters. Analysis of genetic variants of $A P O B$ gene $7673 C>T$ and $12669 \mathrm{G}>A$ polymorphisms showed no significant statistical differences between studied groups and controls.

Conclusions: Analysis of 7673C>T and 12669G $>A$ polymorphisms showed no relationship between specific genetic variants and the risk of gallstones in pre- and postmenopausal women, pointing to the fact that the investigated polymorphisms are not relevant as prognostic factors in gallstone disease in the Caucasian population. Because of the possible contribution of a variety of factors in gallstones pathogenesis the studies are required to take account of additional environmental factors, what may indicate different occurrence between investigated polymorphisms, gallstone disease development and gallstones composition in Caucasians.
\end{abstract}

Key words: menopause, gallstones, apolipoprotein B, genetic polymorphism.

\section{Introduction}

Menopause is associated with significant hormonal changes in the female body. These processes may predispose to many diseases, such as osteoporosis, cardiovascular diseases, obesity and type 2 diabetes. In periand postmenopausal women, estrogen deficiency also leads to lipid disorders, increase in total cholesterol, triglycerides and low-density lipoprotein (LDL) cholesterol as well as decrease in the high-density lipoprotein (HDL) cholesterol level [1, 2]. The progressive decrease in estrogen level changes the lipid profile through expression of genes encoding apoproteins and may be

\footnotetext{
Corresponding author: Anna Bogacz, PhD, Laboratory of Experimental Pharmacogenetics, Department of Clinical Pharmacy and Biopharmacy, Poznan University of Medical Sciences, 6 Święcickiego St., 60-781 Poland, e-mail: aniabogacz23@o2.pl

To cite this article: Rudzińska K, Bogacz A, Kotrych D, Wolski H, Majchrzycki M, Seremak-Mrozikiewicz A, Kosiński B, Czerny B. The APOB gene polymorphism in the pathogenesis of gallstone disease in pre- and postmenopausal women. Prz Menopauzalny 2015; 14 : 35-40. Submitted: 19.08.2014; Accepted: 2.12.2014
} 
important in the pathogenesis of gallstones especially in the case of the formation of cholesterol stones. In addition, estrogens have the suppressant effects for bile acid secretion and influence on the composition and function of the gallbladder $[3,4]$.

In Poland, gallstones account for about $20 \%$ of the population and are more common in women than in men. The most important abnormality associated with lithogenesis is supersaturation of bile with cholesterol, increased formation of cholesterol deposits and impaired contractility of the gallbladder [5, 6]. It was shown that bile becomes lithogenic due to disorders of the proportions between its components, i.e. cholesterol, bile acids and phospholipids [7-9]. Disorders of cholesterol metabolism may result from the existence of different isoforms responsible for transport of lipid compounds. Apolipoprotein B plays an important role in the formation of gallstones [10] and occurs in different isoforms that control the hepatic uptake and cholesterol level [11].

The most studied genetic variant of $A P O B$ gene encoding apolipoprotein $B$ is the Xbal polymorphism in exon 26 (conversion of cytosine to thymine at position 7673 (7673C>T, Thr2488Thr) [12]. Due to the presence of a mutant variant there is no conversion of the threonine residue at position 2488 of ApoB polypeptide chain [13]. However, the Xbal polymorphism of the $A P O B$ gene is responsible for the changes in plasma cholesterol levels [14] and probably plays a role in the pathogenesis of gallstones [11,13]. Another variant of the $A P O B$ gene is the EcoRI polymorphism (12669G>A, Glu4154Lys), in which the presence of mutant allele is associated with the altered level of apolipoprotein $B$, and reduced risk of gallstone formation [13-15].

There is a growing amount of studies that the formation of gallstones may be genetically determined $[16,17]$. The candidate genes include the apolipoprotein $B$ gene involved in cholesterol transport and controlling the amount of excretion of cholesterol $[18,19]$.

The aim of the study was to determine the contribution of $A P O B$ gene $7673 C>T$ and $12669 G>A$ polymorphisms in the pathogenesis of gallstones and analysis of the composition of gallstones in pre- and postmenopausal women.

\section{Material and methods}

\section{Patients}

The study group consisted of 94 Caucasian women (35 premenopausal women, mean age: $39 \pm 6.4$ years and 59 postmenopausal women, mean age: $59 \pm 5.5$ years) qualified for laparoscopic cholecystectomy. The control group consisted of 81 women (23 premenopausal women, mean age: $37 \pm 5.4$ years and 58 postmenopausal women, mean age: $61 \pm 5.3$ years) in whom gallstones and other changes in the bile ducts were excluded. All patients were enrolled in the study in the Department of Laparoscopic Surgery at the Pomeranian Medical University in Szczecin. Blood samples were collected from all patients, while gallstones were also collected from women with cholelithiasis during laparoscopy. In the study group, the parameters of the lipid profile such as total cholesterol, HDL, LDL and triglycerides were also determined.

\section{Analysis of the composition of gallstones}

Assessment of the composition of gallstones (total cholesterol, bile acids, calcium ions and bile pigments) with a powder deposition mass was performed in accordance with the method described by Steen and Blijenberg [20]. Total cholesterol was determined by Color Test - Cholesterol Oxidase/Peroxidase (BioSystems). Determination of total bile acids was performed using the enzyme assay - Merckotest Bile Acids (Merck). The content of bilirubin was determined by spectrophotometry using a Bilirubin Diazotized Sulfanilic-Color Kit (BioSystems). The composition of the fatty acids was evaluated by liquid chromatograph Hewlett Packard 1100 HPLC.

The concentration of cholesterol and bile acids in the tested samples was calculated in relation to the reference test in accordance with the Beer-Lambert law. The obtained cholesterol values $\left(\mathrm{mmol} / \mathrm{cm}^{3}\right)$, bile acids $\left(\mu \mathrm{mol} / \mathrm{cm}^{3}\right)$ and bilirubin $\left(\mathrm{pmol} / \mathrm{dm}^{3}\right)$ were converted to the amount of these compounds in the analyzed samples of gallstones (mg/100 mg of deposit). Calcium carbonate content was determined according to the method described by Scheibler. The volume of evolved $\mathrm{CO}_{2}$ was converted to standard conditions, then the amount of calcium carbonate was expressed as mg/100 mg of deposit.

\section{Genetic analysis}

Determination of $A P O B$ gene $7673 C>T$ and $12669 \mathrm{G}>\mathrm{A}$ polymorphisms was performed using the polymerase chain reaction and restriction fragment length polymorphism (PCR-RFLP). For PCR the following primers were used: ApoBXbaF: 5'-GGA GAC TAT TCA GAA GCT AA-3', ApoBXbaR: 5'-GAA GAG CCT GAA GAC TG A CT-3', ApoBEcoRF: 5'-CTG AGA GAA GTG TCT TCG AAG-3', ApoBEcoRR: 5'-CTC GAA AGG AAG TGT AAT CAC-3'. The polymorphic sites were defined using restriction enzymes for the $A P O B$ gene, such as Xbal (7673C $>$ T, Thr2488Thr, rs693) and EcoRI (12669G>A, Glu4154Lys, rs1042031) (Table I).

\section{Statistical analysis}

Statistical analysis was carried out using the Statistica 10 program (StatSoft). Compatibility of distribution 
Tab. I. Restriction enzymes and product size after hydrolysis

\begin{tabular}{|c|c|c|c|c|}
\hline Polymorphism & Enzyme & Recognition sequence & PCR product (bp) & Product size after hydrolysis (bp) \\
\hline $7673 C>T$ & Xbal & $\begin{array}{l}5^{\prime} . . . \top \downarrow \text { } C \text { T A G A...3' } \\
3^{\prime} \ldots \text { A G A T C } \uparrow \text { T...5' }\end{array}$ & 710 & $\begin{array}{c}\text { CC }(710) \\
\text { CT }(710,433,277) \\
\text { TT }(433,277)\end{array}$ \\
\hline $12669 A>G$ & EcoRI & $\begin{array}{l}5^{\prime} . . . \mathrm{G} \downarrow \text { A A T T C....3' } \\
3^{\prime} . . . \text { C T T A A } \uparrow \text { G...5' }\end{array}$ & 480 & $\begin{array}{c}\mathrm{AA}(480) \\
\text { AG }(480,253,227) \\
\mathrm{GG}(253,227)\end{array}$ \\
\hline
\end{tabular}

of genotypes with Hardy-Weinberg law, and the frequencies of genotypes and alleles between groups were analyzed using Fisher's exact test. Confidence intervals $(95 \% \mathrm{Cl})$ were determined using the Newcombe-Wilson method. In the analysis of differences of the gallstones composition between the studied genotypes MannWhitney $U$ test was used. The values of $p<0.05$ were considered as a statistical significant difference.

\section{Results}

\section{Analysis of lipid parameters and composition of gallstones}

In the group of pre- and postmenopausal women with cholelithiasis it was observed a slight increase in the total cholesterol $(210.1 \pm 34.7 \mathrm{mg} / \mathrm{dl})$ and normal values of $\mathrm{HDL}$ lipid fraction $(58.4 \pm 15.3 \mathrm{mg} / \mathrm{dl})$, LDL lipid fraction $(121.8 \pm 31.5 \mathrm{mg} / \mathrm{dl})$ and triglycerides $(134.1 \pm 81.8 \mathrm{mg} / \mathrm{dl})$. Furthermore, in the postmenopausal women analysis of the composition of the gallstones showed a statistically significant lower level of cholesterol (61.7 mg/100 mg) compared to the premenopausal women $(85.7 \mathrm{mg} / 100 \mathrm{mg}, p<0.05)$ (Table II). Additionally, comparing the contents of calcium carbonate $\left(\mathrm{CaCO}_{3}\right)$ in the gallstones significantly higher levels of carbonate $(15.5 \mathrm{mg} / 100 \mathrm{mg})$ in women after menopause were noted compared to the premenopausal group (8.9 mg/100 mg, $p<0.05)$.
Moreover, in postmenopausal women the analysis of the total calcium content of gallstones showed its higher level (7.4 vs. 4.2, NS). Also, higher levels of bile acids were observed in postmenopausal women (2.3 vs. 1.4, NS) (Table II). The composition of all bile acids in the analyzed gallstones in women after menopause also showed higher levels of acids tested, except cholic and chenodeoxycholic acid (Table III).

\section{Analysis of the APOB gene $7673 \mathrm{C}>\mathrm{T}$ polymorphism}

Analyzing the $A P O B$ gene $7673 C>T$ polymorphism, frequencies of CC, TT and CT genotypes in premenopausal women were comparable to the group of healthy women and women with cholelithiasis. In both these groups, the heterozygous genotype was observed with higher frequency compared to the other genotypes (Table IV).

In addition, analysis of homozygous CC and TT genotypes showed comparable frequencies of their occurrence in postmenopausal women both in healthy patients as well as with cholelithiasis. In both groups (pre- and postmenopausal women) heterozygous genotype CT was also performed with the similar frequency (Table $\mathrm{V}$ ).

\section{Analysis of the APOB gene $12669 \mathrm{G}>\mathrm{A}$ polymorphism}

In the premenopausal women the frequencies of $\mathrm{GG}, \mathrm{AA}$ and $\mathrm{GA}$ genotypes of $A P O B$ gene $12669 \mathrm{G}>\mathrm{A}$ pol-

Tab. II. The composition of gallstones in pre- and postmenopausal women (mg/100 mg of deposit)

\begin{tabular}{|c|c|c|c|c|c|}
\hline & Study group & Total cholesterol & $\mathrm{CaCO}_{3}$ & Total calcium & Bile acids \\
\hline \multirow{2}{*}{$\begin{array}{l}\text { Women with } \\
\text { cholelithiasis, } \\
n=94\end{array}$} & Before menopause, $n=35$ & $85.7 \pm 5.9$ & $8.9 \pm 5.6$ & $4.2 \pm 2.6$ & $1.4 \pm 0.4$ \\
\hline & After menopause, $n=59$ & $61.7 \pm 11.5^{*}$ & $15.5 \pm 4.2^{\star}$ & $7.4 \pm 2.1$ & $2.3 \pm 0.9$ \\
\hline
\end{tabular}

Tab. III. The composition of bile acids in the pathogenesis of gallstones in pre- and postmenopausal women

\begin{tabular}{|c|c|c|c|c|c|c|c|}
\hline & TCA & TCDCA & GCA & GCDCA & CA & CDCA & LCA \\
\hline $\begin{array}{l}\text { Women with cholelithiasis, } \\
n=94\end{array}$ & $0.10 \pm 0.19$ & $0.18 \pm 0.27$ & $0.52 \pm 0.56$ & $0.34 \pm 0.41$ & $0.12 \pm 0.32$ & $0.17 \pm 0.31$ & $2.08 \pm 1.17$ \\
\hline $\begin{array}{l}\text { Premenopausal women, } \\
n=35\end{array}$ & $0.02 \pm 0.05$ & $0.03 \pm 0.07$ & $0.24 \pm 0.17$ & $0.28 \pm 0.27$ & $0.08 \pm 0.09$ & $0.21 \pm 0.17$ & $0.58 \pm 0.33$ \\
\hline $\begin{array}{l}\text { Postmenopausal women, } \\
n=59\end{array}$ & $0.21 \pm 0.22$ & $0.19 \pm 0.20$ & $0.58 \pm 0.33$ & $0.23 \pm 0.26$ & $0.03 \pm 0.05$ & $0.02 \pm 0.09$ & $0.64 \pm 0.52$ \\
\hline
\end{tabular}


Tab. IV. The prevalence of genotypes and alleles of the tested polymorphism of the $A P O B$ gene in premenopausal women with cholelithiasis and in the control group

\begin{tabular}{|c|c|c|c|c|c|c|c|}
\hline & \multicolumn{2}{|c|}{$\begin{array}{l}\text { Control group } \\
\text { (healthy women) }\end{array}$} & \multicolumn{2}{|c|}{$\begin{array}{c}\text { Study group } \\
\text { (women with cholelithiasis) }\end{array}$} & \multirow[t]{2}{*}{ OR } & \multirow[t]{2}{*}{$95 \% \mathrm{Cl}$} & \multirow[t]{2}{*}{$p$} \\
\hline & $\begin{array}{l}\text { Observed } \\
n(\%)\end{array}$ & $\begin{array}{c}\text { Expected } \\
\%\end{array}$ & $\begin{array}{l}\text { Observed } \\
n(\%)\end{array}$ & $\begin{array}{c}\text { Expected } \\
\%\end{array}$ & & & \\
\hline \multicolumn{8}{|c|}{ АРОВ $7673 C>T$} \\
\hline $\mathrm{CC}$ & $5(21.7)$ & 27.2 & $9(25.7)$ & 31.0 & 1.24 & $0.31-5.54$ & 0.49 \\
\hline TC & $14(60.9)$ & 49.9 & $21(60.0)$ & 49.4 & 0.96 & $0.28-3.20$ & 0.58 \\
\hline $\mathrm{TT}$ & $4(17.4)$ & 22.9 & $5(14.3)$ & 19.6 & 0.79 & $0.15-4.54$ & 0.51 \\
\hline Total & $23(100)$ & - & 35 (100) & - & - & - & - \\
\hline C & $24(52.2)$ & - & $39(55.7)$ & - & 1.15 & $0.51-2.60$ & 0.43 \\
\hline $\mathrm{T}$ & $22(47.8)$ & - & $31(44.3)$ & - & 0.85 & $0.38-1.96$ & 0.43 \\
\hline Total & 46 (100) & - & 70 (100) & - & - & - & - \\
\hline \multicolumn{8}{|c|}{ APOB $12669 \mathrm{G}>\mathrm{A}$} \\
\hline GG & $13(56.5)$ & 54.6 & $20(57.1)$ & 55.2 & 1.03 & $0.31-3.36$ & 0.58 \\
\hline GA & $8(34.8)$ & 38.6 & $12(34.3)$ & 38.2 & 0.98 & $0.28-3.47$ & 0.59 \\
\hline AA & $2(8.7)$ & 6.8 & $3(8.6)$ & 6.6 & 0.98 & $0.10-9.72$ & 0.66 \\
\hline Total & $23(100)$ & - & $35(100)$ & - & - & - & - \\
\hline G & 34 (73.9) & - & $52(74.3)$ & - & 1.02 & $0.39-2.57$ & 0.57 \\
\hline$A$ & $12(26.1)$ & - & $18(25.7)$ & - & 0.98 & $0.39-2.54$ & 0.57 \\
\hline Total & $46(100)$ & - & 70 (100) & - & - & - & - \\
\hline
\end{tabular}

Tab. V. The prevalence of genotypes and alleles of the tested polymorphism of the $A P O B$ gene in postmenopausal women with cholelithiasis and in the control group

\begin{tabular}{|c|c|c|c|c|c|c|c|}
\hline & \multicolumn{2}{|c|}{$\begin{array}{l}\text { Control group } \\
\text { (healthy women) }\end{array}$} & \multicolumn{2}{|c|}{$\begin{array}{c}\text { Study group } \\
\text { (women with cholelithiasis) }\end{array}$} & \multirow[t]{2}{*}{ OR } & \multirow[t]{2}{*}{$95 \% \mathrm{Cl}$} & \multirow[t]{2}{*}{$p$} \\
\hline & $\begin{array}{l}\text { Observed } \\
n(\%)\end{array}$ & $\begin{array}{c}\text { Expected } \\
\%\end{array}$ & $\begin{array}{l}\text { Observed } \\
n(\%)\end{array}$ & $\begin{array}{c}\text { Expected } \\
\%\end{array}$ & & & \\
\hline \multicolumn{8}{|c|}{ APOB $7673 C>T$} \\
\hline $\mathrm{CC}$ & $15(25.9)$ & 27.6 & $17(28.8)$ & 29.4 & 1.16 & $0.47-2.85$ & 0.44 \\
\hline TC & $31(53.4)$ & 49.9 & $30(50.9)$ & 49.7 & 0.90 & $0.41-1.98$ & 0.46 \\
\hline $\mathrm{TT}$ & $12(20.7)$ & 22.5 & $12(20.3)$ & 20.9 & 0.98 & $0.36-2.66$ & 0.57 \\
\hline Total & $58(100)$ & - & $59(100)$ & - & - & - & - \\
\hline $\mathrm{C}$ & $61(52.6)$ & - & $64(54.2)$ & - & 1.07 & $0.62-1.84$ & 0.45 \\
\hline $\mathrm{T}$ & $55(47.4)$ & - & $54(45.8)$ & - & 0.93 & $0.54-1.61$ & 0.45 \\
\hline Total & $116(100)$ & - & $118(100)$ & - & - & - & - \\
\hline \multicolumn{8}{|c|}{ APOB $12669 \mathrm{G}>\mathrm{A}$} \\
\hline GG & $38(65.5)$ & 62.9 & $37(62.7)$ & 59.5 & 0.89 & $0.39-2.02$ & 0.45 \\
\hline GA & $16(27.6)$ & 32.8 & $17(28.8)$ & 35.3 & 1.06 & $0.43-2.58$ & 0.52 \\
\hline $\mathrm{AA}$ & $4(6.9)$ & 4.3 & $5(8.5)$ & 5.2 & 1.25 & $0.25-6.64$ & 0.51 \\
\hline Total & $58(100)$ & - & $59(100)$ & - & - & - & - \\
\hline G & $92(79.3)$ & - & 87 (73.7) & - & 0.84 & $0.43-1.64$ & 0.35 \\
\hline A & $24(20.7)$ & - & $27(26.3)$ & - & 1.19 & $0.61-2.33$ & 0.35 \\
\hline Total & $116(100)$ & - & $118(100)$ & - & - & - & - \\
\hline
\end{tabular}


ymorphism were comparable to healthy women and with cholelithiasis. In both groups the homozygous GG genotype occurred more frequently (over 55\%) compared to a homozygous AA genotype (Table IV).

On the other hand, in postmenopausal women analysis of frequency of GG, GA and AA genotypes of $A P O B$ gene $12669 \mathrm{G}>\mathrm{A}$ polymorphism showed no significant statistical differences. In the healthy patients and women with cholelithiasis, homozygous GG genotype performed with a significantly greater frequency accounting for over $60 \%$ of cases, while the homozygous AA genotype constituted a few percent in the group of women studied (Table V).

Furthermore, analysis of the components of gallstones with studied polymorphisms of the $A P O B$ gene did not show any significant correlation of parameters investigated in pre- and postmenopausal women with cholelithiasis.

\section{Discussion}

Cholelithiasis is a major problem, especially in the developing countries. Its pathogenesis is still subject of research [21, 22]. It is suggested that genetic predisposition and environmental factors are the cause of cholesterol gallstone disease $[18,23]$. Currently, data are lacking for the existence of a link between the occurrence of gallstones, the chemical composition of gallstones and certain genetic factors [21, 22].

The conducted studies concern mainly the polymorphisms of genes determining the incidence of cholesterol gallstones [24]. Recent studies have found that changes within some polymorphic genes encoding proteins involved in the transport of cholesterol and bile acids can be correlated with the risk of cholelithiasis [25-27]. Also, in the Caucasian population the $A P O B$ genetic variants have been studied in aspect of linkages with the lipid profile [12, 28, 29].

In our study, we conducted an analysis of $A P O B$ gene $7673 C>T$ and $12669 \mathrm{G}>\mathrm{A}$ polymorphisms in preand postmenopausal women, as well as analysis of the potential relationship of these variants with the transport and metabolism of cholesterol. The results suggest a lack of correlation between analyzed APOB polymorphisms and risk of cholelithiasis in pre- and postmenopausal women. We only observed a change in the composition of gallstones between the analyzed groups which concerned the particularly low level of total cholesterol and increase in calcium carbonate in postmenopausal women compared to premenopausal women These observations also concern an increase of level of certain bile acids in the composition of gallstones in postmenopausal women.

Studies on the $A P O B$ gene $7673 C>T$ and $12669 G>A$ polymorphisms and their significance in the pathogenesis of cholelithiasis are inconclusive. The presence of the mutated allele of $2669 \mathrm{G}>\mathrm{A}$ polymorphism is mainly associated with altered level of apoB lipoprotein [30, 31]. Tan et al. conducted interesting observations on this genetic variant in the Chinese population. They showed a 4-fold decrease in the risk of gallstone formation in carriers of the mutated AA genotype and 1.75fold reduction of risk in all carriers of the mutant $A$ allele of the $A P O B$ gene $12669 \mathrm{G}>\mathrm{A}$ polymorphism [32]. These observations were not confirmed in the Caucasian population [33].

In the present study, when analyzing the $A P O B$ gene $7673 C>T$ polymorphism we observed that the frequency of genotypes and alleles showed no significant differences between women with cholelithiasis and a group of healthy women before and after menopause. Similarly, in the Hindu and Polish population, there was no relationship between the presence of polymorphic variants and the development of gallstone disease [33, 34]. In addition, Hegele et al. [35] suggested that the observed frequencies of alleles of $A P O B$ gene $7673 C>T$ polymorphism are different between the studied populations. Furthermore, in the Caucasian population, a much higher frequency of $7673 \mathrm{~T}$ allele was noted compared to Asians belonging to the Chinese population [36, 37]. Moreover, in some studies, there was no correlation between the $7673 \mathrm{~T}$ allele and cholesterol level $[35,38]$.

In contrast to the above studies, analysis conducted in Mexico suggest the relationship between the concentration of apolipoprotein B in serum and gallbladder disease pathogenesis [39]. It was also found that the presence of the mutant $7673 \mathrm{~T}$ allele is associated with higher levels of cholesterol and LDL and thus may be a marker of the increased risk of gallstone disease in the population [13]. Also, Law et al. [40] and RajputWilliams et al. [41] showed a positive correlation between the mutant 7673T allele and the increase in the cholesterol level.

So far, the results on the relationship between APOB polymorphism and plasma lipids and lipoproteins related to the risk of gallstone disease in the studied populations are ambiguous. Hence, further analysis on large populations are necessary taking into account other factors, such as ethnicity, age, gender, hormonal status, smoking or dietary differences.

\section{Conclusions}

Our study did not indicate a significant association of the $A P O B$ gene $7673 C>T$ and $12669 \mathrm{G}>\mathrm{A}$ polymorphisms with the risk of gallstones in women before and after menopause, pointing to the fact that these variants do not matter as prognostic factors for cholelithiasis in the Caucasian population. Due to the possible contribution of a variety of factors in the pathogenesis of gallstones further studies are required to take ac- 
count of additional environmental factors, which may point to still other relationship between the occurrence of studied polymorphisms and the development of gallstones in Caucasians.

\section{Disclosure}

Authors report no conflict of interest.

\section{References}

1. Hu FB, Grodstein F, Hennekens $\mathrm{CH}$, et al. Age at natural menopause and risk of cardiovascular disease. Arch Intern Med 1999; 159: 1061-1066.

2. Godziejewska-Zawada M. Otyłość i cukrzyca u kobiet w okresie menopauzy - zapobieganie i leczenie. Prz Menopauzalny 2013; 12: 5-9.

3. Portincasa P, Moschetta A, Palasciano G. Cholesterol gallstone disease. Lancet 2006; 368: 230-240.

4. Mesalic L, Tupkovic E, Kendic S, et al. Correlation between hormonal and lipid status in women in menopause. Bosn J Basic Med Sci 2008; 8: 188-192.

5. Silva MA, Wong T. Gallstones in chronic liver disease. J Gastrointest Surg 2005; 9: 739-776.

6. Ryżko J, Górczewska M, Jankowska I, et al. Patogeneza kamicy żółciowej. Pediatria Współczesna Gastroenterologia, Hepatologia i Żywienie Dziecka 2011; 13: 50-54.

7. Vasiliy IR. Concept of the pathogenesis and treatment of cholelithiasis. World J Hepatol 2012; 4: 18-34.

8. Yuan ZB, Han TQ, Jiang ZY, et al. Expression profiling suggests a regulatory role of gallbladder in lipid homeostasis. World J Gastroenterol 2005; 11: 2109-2116.

9. Portincasa P, Di Ciaula A, van Berge-Henegouwen GP. Smooth muscle function and dysfunction in gallbladder disease. Curr Gastroenterol Rep 2004; 6: 151-162.

10. Roberts-Thomson IC, Butler WJ. Genetic disorders in gastroenterology and hepatology: polymorphism and gallstones. J Gastroenterol Hepatol 2005; 20: 319-320.

11. Mittal B, Mittal RD. Genetics of gallstone disease. J Postgraduate Med 2002; 48: 149-152.

12. Benn M, Nordestgaard BG, Jensen JS, et al. Increased low-density lipoprotein levels in both polymorphism in APOB associated with genders in the general population. J Clin Endocrinol Metab 2005; 90: 5797-5803.

13. Han T, Jiang Z, Suo G, et al. Apolipoprotein B-100 gene Xbal polymorphism and cholesterol gallstone disease. Clin Genet 2000; 57: 304-308.

14. Juvonen T, Savolainen MJ, Kairaluoma MI, et al. Polymorphisms at the apoB, apoA-1 and cholesteryl ester transfer protein gene loci in patients with gallbladder disease. J Lipid Res 1995; 36: 804-812.

15. Davis RA, Miyake JH, Hui TY, et al. Regulation of cholesterol 7a-hydroxylase: BAREly missing a SHP. J Lipid Res 2002; 43: 533-543.

16. van Mil SW, van der Woerd WL, van der Brugge G, et al. Benign recurrent intrahepatic cholestasis type 2 is caused by mutations in ABCB11. Gastroenterology 2004; 127: 379-384.

17. Pullinger CR, Eng C, Salen G, et al. Human cholesterol 7a-hydroxylase (CYP7A1) deficiency has a hypercholesterolemic phenotype. J Clin Invest 2002; 110: 109-117.

18. Lammert F, Sauerbruch T. Mechanisms of disease: the genetic epidemiology of gallbladder stones. Nat Clin Pract Gastroenterol Hepatol 2005; 2: 423-433.

19. Wittenburg H, Lammert F. Genetic predisposition to gallbladder stones. Semin Liver Dis 2007; 27: 109-121.
20. Steen G, Blijenberg BG. Chemical analysis of gallstones. Eur J Clin Chem Clin Biochem 1991; 29: 801-804.

21. Katsika D, Grjibovski A, Lammert F, et al. Genetic and environmental in fluences for gallstone disease related diagnoses: a Swedish twin study of 43,141 twin pairs. Hepatology 2005; 41: 1138-1143.

22. Marschall HU, Einarsson C. Gallstone disease. J Intern Med 2007; 261: 529-542.

23. Lammert F, Miquel JF. Gallstone disease: from genes to evidence-based therapy. J Hepatol 2008; 48: 124-135.

24. Dong SH. Molecular genetics of cholesterol gallstone disease: LITH genes. Hanyang Med Rev 2007; 27: 29-34.

25. Buch S, Schafmayer C, Volzke $\mathrm{H}$, et al. A genome-wide association scan identifies the hepatic cholesterol transporter ABCG8 as a susceptibility factor for human gallstone disease. Nat Genet 2007; 39: 995-999.

26. Grunhage F, Acalovschi M, Tirziu S, et al. Increased gallstone risk in humans conferred by common variant of hepatic ATP-binding cassette transporter for cholesterol. Hepatology 2007; 46: 793-801.

27. Renner O, Harsch S, Schaeffeler E, et al. A variant of the SLC10A2 gene encoding the apical sodium-dependent bile acid transporter is a risk factor for gallstone disease. PLoS One 2009; 4: e7321.

28. Kathiresan S, Melander O, Anevski D, et al. Polymorphisms associated with cholesterol and risk of cardiovascular events. N Engl J Med 2008; 358: 1240-1249.

29. Ronald J, Rajagopalan R, Ranchalis JE, et al. Analysis of recently identified dyslipidemia alleles reveals two loci that contribute to risk for carotid artery disease. Lipids Health Dis 2009; 8: 52-60.

30. De Benedictis G, Rose G, Mazzei R, et al. EcoRI-RFLP of the Apo B gene: a study in a sample group from south Italy. Ann Hum Genet 1991; 55 103-113.

31. Glisic S, Savic I, Alavantic D. Apolipoprotein B gene DNA polymorphisms (EcoRI and Mspl) and serum lipid levels in the Serbian healthy population: interaction of rare alleles and smoking and cholesterol levels. Genet Epidemiol 1995; 12: 499-508.

32. Tan YF, Yang S, Yu RB, et al. Relationship among the Xbal and EcoRI locus polymorphisms of apolipoprotein $B$ gene, serum lipid metabolism and gallstone disease. Zhonghua Yi Xue Za Zhi 2003; 83: 844-847.

33. Kurzawski M, Juzyszyn Z, Modrzejewski A, et al. Apolipoprotein B (APOB) gene polymorphism in patients with gallbladder disease. Arch Med Res 2007; 38: 360-363.

34. Singh MK, Pandey UB, Ghoshal UC, et al. Apolipoprotein B-100 Xbal gene polymorphism in gallbladder cancer. Hum Genet 2004; 114: 280-283.

35. Hegele RA, Huang LS, Herbert PN, et al. Apolipoprotein B-gene DNA polymorphisms associated with myocardial infarction. N Engl J Med 1986; 315: 1509-1515.

36. Pan JP, Chiang AN, Tai JJ, et al. Restriction fragment length polymorphisms of apolipoprotein B gene in Chinese population with coronary heart disease. Clin Chem 1995; 41: 424-429.

37. Scartezini M, Zago MA, Chautard-Freire-Maia EA, et al. The $X-X-/ E+E+$ genotype of the Xbal/EcoRl polymorphisms of the apolipoprotein $B$ gene as a marker of coronary artery disease in a Brazilian sample. Braz Med Biol Res 2003; 36: 369-375.

38. Darnfors C, Wiklund O, Nilsson J, et al. Lack of correlation between the apolipoprotein B Xbal polymorphism and blood lipid levels in a Swedish population. Atherosclerosis 1989; 75: 183-188.

39. Moran S, Duque-Lopez MX, Salmeron-Castro J, et al. Association between serum concentration of apolipoproteins A-I and B with gallbladder disease. Arch Med Res 2003; 34: 194-199.

40. Law A, Wallis SC, Powell LM, et al. Common DNA polymorphism within coding sequence of apolipoprotein B gene associated with altered lipid levels. Lancet 1986; 1: 1301-1303.

41. Rajput-Williams J, Knott TJ, Wallis SC, et al. Variation of apolipoprotein B gene is associated with obesity, high blood cholesterol levels, and increased risk of coronary heart disease. Lancet 1988; 2: 1442-1446. 